\section{Brussels hope after Milan chaos}

\section{Brussels}

WITH the key issue of institutional reform referred, reluctantly by some, to an intergovernmental conference to take place later this year, the approval by heads of government of the European Economic Community (EEC) of the idea to give the Community a new technological dimension may be considered as, at least, one positive result at the end of the two-day summit in Milan. But a series of questions still remain unanswered.

EEC heads agreed that technology in the Community should be strengthened. Thus they agreed that there should be a close link between technological development and the effort to unify the internal market, that technological effort should be closely tied to common policies as on trade policy, that duplication of national efforts should be reduced and money pooled.

The Milan summit also endorsed a Community report on the subject but the heads of government gave no clues as to the form research collaboration would take and who would coordinate it.

Questions of financial support and structure will be considered at an ad hoc meeting on European technology by EEC research ministers and "other qualified representatives of governments" (which may imply industrial participation). Government heads asked the French (perhaps not insignificantly) to convene a meeting in Paris, probably on 17 July. These "technology assizes" will also include the new (from 1986) EEC members Spain and Portugal, as well as non-EEC countries Austria, Sweden, Switzerland and Norway to whom participation in projects will be open and who have expressed an interest. At Milan, two proposals were put forward, the Eureka project in which countries and companies may collaborate unilaterally or in groups according to the dictates of interest and investment capacity, and the Commission proposal which would like to see the Eureka project as part of a flexible structure coordinated on a Community level, with projects operating on the lines of the Joint European Torus at Culham in the United Kingdom.

The Commission proposal has the advantage of being able to fall back on existing structures, and it has the support of the smaller member states which need to share the financial burden of technological research investment. EEC research commissioner Karl-Heinz Narjes has suggested the creation of a corridor in the research budget as well as increasing the share of the budget itself.

The other possibility is that Eureka might develop separately, out of reach of Community control (which would please President Mitterrand) but which would be overseen by an intergovernmental agency which would at the same time keep an eye on the Community programme and would thus coordinate the two. A possible candidate for the job is Viscount Etienne Davignon, ex-EEC research and industry commissioner and father of the much quoted ESPRIT programme which launched cooperation between European industry and universities. In this second case the ten Community countries would be treated as just another member state in

\section{Eureka}

WHILE European heads of state have been debating whether and how to go ahead with Eureka, the French proposal for a joint European technology programme, electronics companies in Europe have been defining projects that their political masters might support. Last week GEC (United Kingdom), Siemens (West Germany), Philips (The Netherlands) and Thompson (France) announced that they have already set up a study group to make joint proposals to Eureka, while the Norwegian computer company Norsk Data and the French defence, space and electronics group, Matra, announced the development of a super-mini-computer, a "Crayette" (for scientific use) under the Eureka banner.

These are some of the first concrete developments to flow from the Eureka idea originally proposed by President Mitterrand of France to provide Europe with an alternative to participation in the US star wars programme. The speed with which they have been put in train would seem to indicate that Eureka has touched a receptive nerve.

According to British GEC, experience of the European Commission's ESPRIT programme for pre-competitive research in information technology, while positive, has indicated the need for more marketoriented cooperation in real product development, which might be stimulated by Eureka. ESPRIT itself has "barely started", but has shown that an "unbiased" organization like the Commission can catalyse cooperation, spanning national frontiers.

A further factor is money. While nothing has been agreed, French sources have suggested that France alone would be prepared to contribute an initial $£ 100$ million to Eureka. Development costs in electronics seem to be increasing exponentially, according to Philips (Eindhoven) directors, so that the potential availability of public pots of gold is stimulating. International cooperation in development would also ease the burden.

What products are in the offing? Derek

participating in Eureka projects

Conceding that Eureka should develop separately would allow at least some member states to get going on technological research while the institutional debate in the EEC continues. For even if the Commission maintains that the proposal is based on existing operational rules, bringing about a "qualitative technological leap forward" will require, as Jacques Delors, president of the European Commission, insisted before the Milan summit, changes to inject dynamism into functioning of community institutions and encourage the creation of an internal market.

Anna Lubinska

\title{
Companies ready to bid for funds
}

Roberts, technical director of GEC, appears to have in mind new transportation systems and traffic control systems, while pan-European cellular radio networks are also in the air. The French have also been pushing for the development of a large European super-computer to rival the Cray machines.

Meanwhile, Norsk Data, which first made its name by supplying the computer control systems for the super proton synchrotron at CERN, and Matra are working together on a more immediate project, to develop not a European Cray, but something that might be described as a "Crayette".

The two companies have already been cooperating on the development of a 32 bit mini-computer to supplant Digital Equipment's ubiquitous VAX and, says Matra, they have identified a market gap for desk-top vectorial machines. These, like the Cray, offer a degree of parallel processing, essentially performing instant matrix multiplications on columns of numbers ("vectors") many elements long. Such computers are proving essential in number-crunching operations as in quantum chemistry, atmospheric modelling and seismology, but they are at present very expensive, ranging from $£ 1$ million to $£ 10$ million.

Norsk Data and Matra, however, hope to come on the market (with the help of Eureka) in two years with a vectorial machine of some "hundreds of millions of operations per second" at a price of only $£ 100,000$ to $£ 1$ million, compared with the current price of a VAX of around $£ 60,000$. Matra is aiming at the market for 32-bit minis in 3-4 years time.

One Cambridge quantum chemist said last week that "there's no doubt that this is the way it'll go" and that the Matra/Norsk Data proposal sounded "extremely competitive". The present cost of vectorial computing is a real hindrance to its development, he said. Companies such as Convex of the United States would be in competition with the European group, however. 